\title{
Serum concentrations of C-reactive protein (CRP) in lean and overweight dogs
}

\author{
Anna Hillström ${ }^{1 *}$, Josefin Söder ${ }^{2}$, Sara Wernersson², Ragnvi Hagman ${ }^{1}$ \\ From Animal Obesity - causes, consequences and comparative aspects \\ Uppsala, Sweden. 14-16 June 2015
}

\section{Introduction}

Obesity in dogs has been associated with both increased and decreased blood C-reactive protein (CRP) concentrations.

\section{Objectives}

To compare serum CRP concentrations between lean and overweight healthy dogs, and to investigate if results are affected by how dogs are classified as healthy; by owner interview only, or in combination with physical examination and laboratory testing.

\section{Methods}

28 adult male intact Labrador Retrievers, reported to be healthy by their owners, were included. 12 dogs were categorized as lean (body condition score, BCS, $\leq 5$ ) and 16 as overweight ( $\mathrm{BCS} \geq 6$ ). Physical examination and laboratory testing were performed. Serum CRP concentrations were measured with a canine-specific high-sensitivity CRP assay (Gentian hsCRP). Mann Whitney U test $(\alpha=0.05)$ was used for data analyses, performed before and after exclusion of dogs with any abnormality detected.

\section{Results}

The median (range) CRP concentration was $1.0(<0.5-$ 10.0) $\mathrm{mg} / \mathrm{l}$ in lean and 1.1 (0.5-6.4) $\mathrm{mg} / \mathrm{l}$ in overweight $\operatorname{dogs}(\mathrm{p}=0.87)$. Minor abnormalities were found at physical examination in $11 \mathrm{dogs}$, and increased alanine aminotransferase (ALAT) values were detected in 2 dogs. After excluding these dogs, the median CRP concentrations in lean $(n=4)$ and overweight $(n=11)$ dogs were 0.6

\footnotetext{
* Correspondence: anna.hillstrom@slu.se

'Department of Clinical Sciences, Swedish University of Agricultural Sciences, Uppsala, Sweden

Full list of author information is available at the end of the article
}

$(<0.5-1.4) \mathrm{mg} / \mathrm{l}$ and $1.1(0.5-6.4) \mathrm{mg} / \mathrm{l}$, respectively $(\mathrm{p}=0.17)$.

\section{Conclusions}

CRP concentrations did not differ significantly between lean and overweight dogs. Physical examination revealed minor abnormalities in over $1 / 3$ of the dogs, despite owners' assessment as healthy. To avoid abnormalities that could affect results when studying CRP in canine obesity, clinical assessment of health status is important.

\footnotetext{
Authors' details

'Department of Clinical Sciences, Swedish University of Agricultural Sciences, Uppsala, Sweden. ${ }^{2}$ Department of Anatomy, Physiology and Biochemistry, Swedish University of Agricultural Science, Uppsala, Sweden.
}

Published: 25 September 2015

doi:10.1186/1751-0147-57-S1-015

Cite this article as: Hillström et al:: Serum concentrations of C-reactive protein (CRP) in lean and overweight dogs. Acta Veterinaria Scandinavica 2015 57(Suppl 1):015.

\section{Submit your next manuscript to BioMed Central and take full advantage of: \\ - Convenient online submission \\ - Thorough peer review \\ - No space constraints or color figure charges \\ - Immediate publication on acceptance \\ - Inclusion in PubMed, CAS, Scopus and Google Scholar \\ - Research which is freely available for redistribution \\ Submit your manuscript at www.biomedcentral.com/submit}

